\title{
WORSHIP AND ETHICS IN ROMANS 12
}

\author{
David Peterson
}

\section{Summary}

What is the link between worship and ethics in Romans 12? Käsemann rather too easily proposes that the mystical tradition of Hellenism is the main inspiration for Paul's thinking and ignores the biblical theological background to Paul's argument and the wider context of Romans. The first two verses of Romans 12 proclaim a reversal of the downward spiral depicted in Romans 1. A new kind of service to God is made possible by the saving work of Jesus. Renewal of the mind is a critical aspect of this, enabling Christians to discern the will of God and do it. Paul does not present a system of casuistry in the rest of Romans but various axhorations and examples consistent with the fundamental perspectives of 12:1-2.

Ernst Käsemann's brief essay 'Worship and Everyday Life. A Note on Romans 12' was first published in 1960.1 With characteristic flair, he set out to demonstrate that in Romans 12 a new stage in Christian ethics is introduced. By 'ethic' he meant 'a system of morality developing logically out of a single nucleus'.2 Everything in the passage is oriented around the theme of worship, which is introduced in the opening verse:

Therefore, I urge you, brothers and sisters, in view of God's mercies, to offer your bodies as a living sacrifice, holy and pleasing to God, which is your understanding worship. (Rom. 12:1, my translation)

What Käsemann calls 'spiritual worship' ( embraces 'the total action both of the individual Christian and the Christian community and sets the paraenesis within a firm theological framework'. ${ }^{3}$ With such an argument, Paul shows us what it means to live under the righteousness of God. The exhortations that follow in Romans 12-15 are 'pointers towards

1'Gottesdienst im Alltag der Welt (zu Rm 12)' in (ed.) W. Eltester, Judentum Urchristentum Kirche. Festschrift für Joachim Jeremias (Berlin, Töpelmann 1960) 165-171. The essay appeared in English in a collection of Käsemann's essays entitled New Testament Questions of Today (London, SCM 1969).

2New Testament Questions, 188.

${ }^{3}$ New Testament Questions, 189. 
the worship which at that time was necessarily something new, which had to be recognized as such and then practised'.

Sacred times and places are superseded by the eschatological public activity of those who at all times and in all places stand 'before the face of Christ' and from this position before God make the everyday round of so-called secular life into the arena of the unlimited and unceasing glorification of the divine will. At this point the doctrines of worship and Christian 'ethics' converge. 4

When Käsemann published his commentary An Die Römer, 5 the argument of his stimulating essay was expanded, providing a more detailed exegesis of the passage and a more comprehensive analysis of Paul's ethic. There is much in Käsemann's approach that I want to endorse, but others have since contributed to this important discussion and my own research has brought me to dispute and modify some of his emphases. 6

\section{The key phrase: 'spiritual worship'}

In his original essay, Käsemann notes how the expression

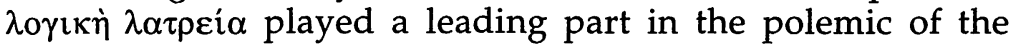
Hellenistic enlightenment against the 'irrational' cultic offerings of the folk religions. It was then modified in a spiritualising sense by Hellenistic mysticism, 'in order to qualify the oratio infusa of the praise rendered to the Godhead as true divine worship by the man endowed with pneuma as representative of the whole creation'.7 So, concludes Käsemann, 'Paul can properly take up this key phrase because in his thought also only the man endowed with pneuma is in a position to offer spiritual worship'. Käsemann's commentary discusses the evidence more thoroughly but still comes to the same

${ }^{4}$ New Testament Questions, 191.

5(Tübingen, Mohr 1980); ET, Commentary of Romans, translated and edited by G. W. Bromiley (Grand Rapids, Eerdmans 1980).

6I am grateful for the opportunity to expand and develop some of the arguments that I put forward in D.G. Peterson, Engaging with God. A Biblical Theology of Worship (Leicester, Apollos 1992; Grand Rapids, Eerdmans 1993) 166-193.

${ }^{7}$ New Testament Questions, 190. Cf. Commentary, 328-9, where the evidence from popular philosophical and mystical treatises is presented in more detail. 
fundamental conclusion. This sets him off on a particular line of approach to Romans 12 with which I want to take issue.

The adjective $\lambda$ orı philosophers, especially the Stoics, for whom it meant

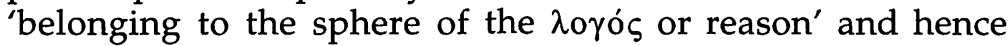
'spiritual' in the sense of 'suprasensual'. 8 Since rationality is what distinguishes human beings from animals and relates them to the gods, traditional sacrifices were repudiated by

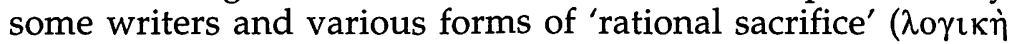
$\theta v \sigma i \alpha)$ were advocated instead. In some texts this refers to attitudes of mind and purity of life. Hellenistic mysticism offered a significant variation on this motif, regarding some form of religious ecstasy or even silence as the proper worship. The Hermetic tracts, probably dating from the third century

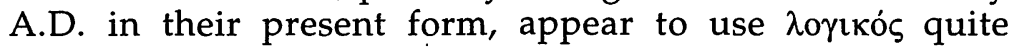
specifically with reference to sacrifices on a rational plane, offered by the rational part of the soul. ${ }^{9}$ Käsemann interprets these tracts to mean that 'the divine Spirit acts in such a way as to make the one who prays his instrument and spokesman',10 and rather too easily proposes that the mystical tradition of Hellenism is the main inspiration for Paul's use of the terminology.

In his commentary, Käsemann notes how Hellenistic Judaism appropriated the motif of 'spiritual sacrifice'. This leads to a refinement of his argument, namely that Paul followed the Diaspora synagogue in its blending of Hellenistic and Jewish ideas about a truly spiritual worship. However, Käsemann effectively ignores what the Old Testament teaches about the ethical implications of ritual worship and fails to

${ }^{8} \mathrm{G}$. Kittel, TDNT 4:142. Note the helpful analysis of relevant texts from various religious and philosophical traditions by E. Ferguson, 'Spiritual Sacrifice in Early Christianity and its Environment', in W. Haase (ed.), Aufstieg und Niedergang der Römischen Welt II 23:2 (Berlin/New York, de Gruyter 1979) 1152-1189. Cf. P. Seidensticker, Lebendiges Opfer (Rom 12,1). Ein Beitrag zur Theologie des Apostels Paulus. (Neutestamentliche Abhandlungen; Münster, Aschendorff 1954) 17-28.

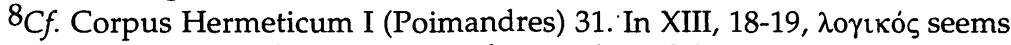
to be connected with the idea that the worship of the reborn person really proceeds from the indwelling divine Logos.

${ }^{10}$ Commentary, 328. For a more thorough and balanced assessment of the evidence, cf. C.E.B. Cranfield, A Critical and Exegetical Commentary on the Epistle to the Romans, 2 vols., ICC (Edinburgh, Clark 1975/9) II, 601-5. 
perceive the biblical theological background to Paul's thought

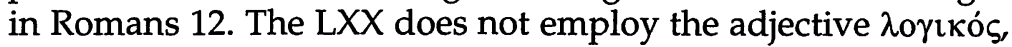
though the Old Testament prophets indicated that God was honoured, not merely by ritual observance, but by a genuine spiritual and moral engagement with him (e.g. Is. 1:10-16; 29:13; Mi. 6:6-8). God's essential requirement was repentance, faith and obedience, especially expressed in the concern to establish righteousness and holiness in the community of his people. Israel was to serve God (LXX $\lambda \alpha \tau \rho \varepsilon v i \varepsilon v)$ with heart and soul, which was another way of speaking about walking in all his ways, loving him and observing all his commands ( $c f$. Dt. 10:12-13; 6:13-15; Josh. 24:14-24). The sacrificial system was designed to promote such a response and not to be a cover-up for sin. In late Judaism, while the need for cultic observance continued to be stressed, deeds of love, and activities such as fasting, prayer and the study of the law were often regarded as being as pleasing to God as temple offerings. 11

So the way for New Testament teaching was forged by Old Testament and inter-testamental writers placing the doing of God's will at the heart of what they said about worship and sacrifice. It is also possible that the apostle chose to use the particular expression $\lambda \mathrm{o} \gamma \mathrm{i} \dot{\eta}$ $\lambda \alpha \tau \rho \varepsilon i \alpha$ as something of a challenge to the spiritualising tradition and nuances which it represented in the Hellenistic world. 'Paul would thus be taking up, in quotation marks as it were, a religious slogan common in certain circles at the time. In so doing he completely transforms the saying, while opposing it to those conceptions of spiritual worship so much in vogue at the time. Certainly no more the bloody animal sacrifices of the past, but nor either the pure interiority of the Mystic. The Christian's spiritual worship involves an extreme of realism-the bodily offering of himself'.12

${ }^{11} C f$. E. Ferguson, 'Spiritual Sacrifice', 1156-1162.

12R. Corriveau, The Liturgy of Life. A Study of the Ethical Thought of St. Paul in his Letters to the Early Christian Communities, Studia 25 (Desclee de Brouwer/Les Éditions Bellarmin, Bruxelles-Paris/Montréal 1970) 179. He

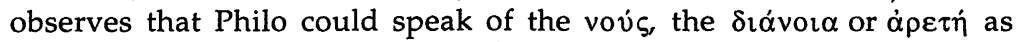
sacrifices but could never speak of the body as a sacrifice, since this whole idea was foreign to his Hellenistic framework of thought. Again, Paul goes beyond anything in the Qumran tradition, where the concern for spiritual sacrifices is set within the context of a highly elaborated concern 
If Paul's expression is translated 'spiritual worship', there is a danger of accenting the inwardness of Christian worship and not taking sufficient account of the fact that we are to yield our bodies to God's service. There is no doubt from passages such as 1 Corinthians 12:3; Ephesians 2:17-22; Philippians 3:3 that the Holy Spirit facilitates the worship of the new covenant era, but that does not mean that we are compelled to translate $\lambda o \gamma \iota \kappa \dot{\eta} \lambda \alpha \tau \rho \varepsilon i \alpha$ as 'spiritual worship'. On the other hand, 'rational worship' may only suggest a contrast between the offering of rational beings and the sacrifice of irrational animals. The mind is certainly central to Paul's perspective here, but the focus is not simply on rationality. The service he calls for is the obedience of faith expressed by those whose minds are being transformed and renewed by God, so that they may no longer be conformed in lifestyle to the values, attitudes and behaviour of 'this age' (Rom. 12:2; cf. Col. 3:9-10; Eph. 4:22-4). Consequently, it may be best to read 'understanding worship', and to recognise from the context that this means 'the worship which is consonant with the truth of the gospel', 13 or the service rendered by those who truly understand the gospel and its implications.

Käsemann is very clear on the fact that 'spiritual worship' for Paul means 'the offering of bodily existence' in the otherwise profane sphere of everyday life. Indeed, 'God lays claim to our corporeality because he is no longer leaving the world to itself, and our bodily obedience expresses the fact that, in and with us, he has recalled to his service the world of which we are a part'. ${ }^{14}$ Nevertheless, he bases much of his argument on the assumption that Paul is propounding 'the universal priesthood of all believers' in Romans 12. This 'priestly' role is given through baptism and is inspired by the Holy Spirit, who enables Christians to be God's instruments on earth, somewhat as in the 'heavenly praise' of Hellenistic mysticism. However, I

for ritual purity in the present and the hope for restoration of ritual sacrifice at a renewed temple in Jerusalem.

${ }^{13}$ Cranfield, Romans II, 605. C.F. Evans, 'Rom 12:1-2: The True Worship', in L. de Lorenzi (ed.), Dimensions de la vie chrétienne (Rome, St. Paul's Abbey 1976) 20-2, argues strongly for the rendering 'rational', and defends it against some critical responses (38-9).

${ }^{14}$ New Testament Questions, 191. This is a brilliant formulation of Paul's thinking in Romans about worship and the fallen world. Cf. Commentary, 329. 
do not think that this is an adequate way to interpret the apostle's argument here. What Paul says about worship in Romans 12 must be understood in the light of what he has previously argued in this letter.

\section{The wider context: worship, sin and redemption}

Foundational to the apostle's thinking about worship is his teaching about humanity's refusal to glorify and serve God acceptably (1:18-2:29). Here Paul reflects the OT perspective that the knowledge of God should lead to appropriate worship ( $\lambda \alpha \tau \rho \varepsilon v i \varepsilon \imath$, the cognate of $\lambda \alpha \tau \rho \varepsilon i \alpha$ is used in 1:25). Associated with the failure to acknowledge and glorify God is a futility of thinking and a darkening of 'their foolish hearts'. Humanity is fundamentally impaired at the level of understanding and judgement because of the rejection of the true knowledge of God. It is significant, therefore, that Paul later links the renewing of the mind with the notion of right worship being restored through the work of Christ (12:1-2; cf. 1:28; 2:18). ${ }^{15}$

The opening chapters of Romans illustrate how both Jews and Gentiles have failed in their own distinctive ways to reverence and serve God acceptably. Refusal to glorify God as God has its consequence in every form of wickedness, abuse, hypocrisy and injustice in human relationships. False worship and immorality are closely linked. Consequently, God has abandoned men and women to the consequences of their rebellion against him, as an expression of his wrath, anticipating the final revelation of his wrath on the day of judgement (Rom. 1:18, 24, 26, 28; 2:5).

Against this background, it is significant that Paul's exposition of the work of Christ in 3:24-5 employs a distinctive cultic metaphor. The apostle first explains how believers are justified freely by God's grace 'through the redemption that came by Christ Jesus' (3:24). Changing the imagery, Paul goes on to argue that God provided Jesus as the ultimate sacrifice, 'a sacrifice of atonement by means of his blood, to be received

${ }^{15}$ For other verbal links between Rom. 1 and 12, cf. C.F. Evans, "The True Worship', 31, and M. Thompson, Clothed with Christ The Example and Teaching of Jesus in Romans 12.1 - 15.13, JSNTSS 59 (Sheffield, Sheffield Academic Press 1991) 80-3. 
through faith'.16 Some commentators have argued that the word $i \lambda \alpha \sigma \tau$ njov here portrays Christ as the anti-type of the 'mercy seat' or 'place of atonement' which covered the ark in the holy of holies (e.g., Ex. 25:17-22; Lv. 16:14, 15-16). However, it may be more appropriate to view Christ as the 'means of atonement' or 'sacrifice of atonement', rather than as the 'place of atonement'.17 The expression 'by means of his blood' points to the atoning significance of his death. The wrath of God is averted by Jesus' death though, paradoxically, as in Old Testament teaching about the sacrificial system, it is God who provides the means of atonement. The sprinkling of sacrificial blood was a crucial part of the annual Day of Atonement sin offering (Lev. 16) and Paul would seem to be indicating that Jesus has fulfilled and replaced that central rite of Old Testament religion ( $c f$. Heb. 9:11-14), rendering the whole sacrificial system no longer necessary.

In Romans 5:8-9 Christ's blood or death is again highlighted as the means by which sinners are justified and saved from the wrath of God. He offers the eschatological sacrifice, which secures for believers all the blessings of the New Covenant and the kingdom of God. However, in 5:19 it is through his obedience that 'the many will be made righteous'. As Adam headed the line of disobedience and sin, Jesus heads the line of humanity which lives under the sign of obedience. The atoning value of his obedience, which culminates in his death, lies in the fact that he surrenders himself completely to the Father as the representative of sinful humanity. So Paul's argument suggests that we may only relate to God on the basis of Christ's perfect 'worship' or service to God, which is his selfoffering.

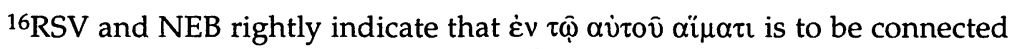
with i $\lambda \alpha \sigma \tau$ inpov, showing that it was by means of his blood/death that Christ was a sacrifice of atonement, rather than with $\delta i \dot{\alpha} \pi i \sigma \tau \varepsilon \omega \varsigma$ ('through faith in his blood', as in KJV and NIV). Cf. C.E.B. Cranfield, Romans I, 210211.

${ }^{17}$ Cf. C.E.B. Cranfield, Romans I, 214-218, for a helpful discussion of the issues. He suggests that the absence of the definite article before $i \lambda \alpha \sigma \tau$ inpov in Rom. 3:25 is an argument against identifying Christ as the anti-type of the mercy seat. Furthermore, 'the mercy-seat would surely be more appropriately regarded as a type of the Cross' (215). Contrast the argument of D.J. Moo, The Wycliffe Exegetical Commentary Romans 1-8 (Chicago, Moody 1991) 232-8. 
Romans 6:1-10 makes it clear that baptism into Christ means baptism into his death, in order to live with him and for him (cf. 2 Cor. 5:15). Christians enter into fellowship with Christ in his total self-surrender to the will of the Father in order to find acceptance with the Father through his atoning work on their behalf. The moral implication of this is to live out the new obedience which baptism into Christ's death entails (Rom. 6:11-23; cf. 12:1-2). Christian obedience is made possible by the self-giving obedience of Jesus Christ. We are to count ourselves 'dead to sin' and 'alive to God in Christ Jesus', because of our trust in the redemptive power of his death and resurrection (6:11). We are consequently challenged to offer ourselves to God 'as those who have been brought from death

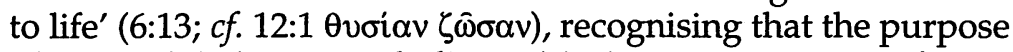

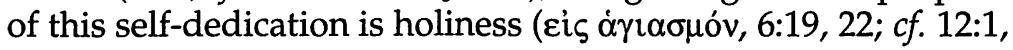
$\theta v \sigma i \alpha v \dot{\alpha} \gamma i \alpha v)$.

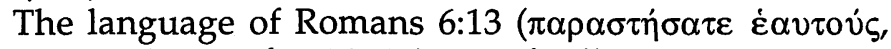
'present yourselves'; cf. 6:16,19) specifically anticipates 12:1 ( $\pi \alpha \rho \alpha \sigma \tau \hat{\eta} \sigma \alpha \imath \tau \dot{\alpha} \sigma \omega \dot{\omega} \mu \alpha \alpha \dot{v} \mu \hat{\omega} v$, 'present your bodies'). The verb is the same but the imagery is that of ownership and servitude in chapter 6, rather than sacrificial offering. Of course, the note of

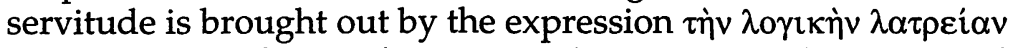
v $\mu \omega \hat{v}$ ('your understanding service') in 12:1. But this term and the related expression $\theta v \sigma i \alpha v \zeta \hat{\omega} \sigma \alpha v$ ('living sacrifice') give the notion of Christian obedience a decidedly cultic nuance. In other words, Romans 12:1 restates some of the perspectives of Romans 3-6, using modified cultic language.

Worship terminology is reintroduced at this key point in Paul's argument to demonstrate how the problems created by humanity's failure to worship and serve God appropriately (Romans 1-2) have been dealt with by God himself. Reconciliation with the Creator brings renewal in human relationships and a transformation of behaviour. This reverses the terrible situation portrayed in the early chapters of Paul's letter. Jews and Gentiles can now engage with God in a new way, on the basis of Christ's atoning sacrifice, offering the worship that is pleasing to him. Cultic terms are employed again by the apostle at another critical point in the letter (15:16), to describe the ministry by which he enables the Gentiles to present themselves as 'an offering acceptable to God, sanctified by the Holy Spirit'. It is the preaching of the gospel about 
Christ and his saving work that makes possible the worship described in 12:1.18 If Jesus' death is the unique and never-tobe-repeated sin offering of the New Covenant, faith expressed in obedience is the 'holocaust' or 'burnt offering' which Christians can offer to God because of, and on the basis of, Jesus' sin-offering. ${ }^{19}$ 'Dying with Christ, being crucified with him in baptism, stamps the whole earthly life of the Christian, sanctified by his Spirit, with the cultic character of his death on the cross.' 20

Much scholarly discussion has focused on the link between Romans 12 and the preceding argument of the letter. Some have suggested that the ouv ('therefore') of v. 1 is only transitional, implying no important logical or inner connection between what precedes and what follows. Furthermore, the expression $\delta i \dot{\alpha} \tau \hat{\omega} v$ oi $\tau \tau \iota \rho \mu \hat{\omega} v \tau o \hat{v} \Theta \varepsilon \circ \hat{v}$ ('by the mercies of God') can be taken quite narrowly to mean that 'Paul's authority in making the appeal is grounded in and expressive of his own experience and role as agent of God's mercy (11:13-14, 22, 30$31)^{\prime} .21$ However, it is not just Paul's experience of the mercy of God that is the ground of his appeal. The immediately preceding paragraph is a call to join him in praise of God for the depth of the riches of divine wisdom, knowledge and judgement (11:33-6). This doxology is a conclusion to the

${ }^{18} C f$. D.G. Peterson, Engaging with God, 180-2, for a discussion of Rom. 15:16 and its implications. Against those who argue that $\dot{\eta} \pi \rho \circ \sigma \phi \circ \rho \dot{\alpha} \tau \hat{\omega} v$ $\dot{\varepsilon} \theta v \omega \hat{v}$ means 'the offering which consists of the Gentiles', the preceding teaching of 12:1 demands that 'the offering made by the Gentiles' be read at $15: 16$.

${ }^{19} \mathrm{M}$. Thompson, Clothed with Christ, 80 , is more cautious about the explicit link between the sacrifice of Christ and the sacrifice of Christians in Rom. 12:1, but he argues that there is 'more than a causal relation in Paul's theology'. I do not think his conclusion about the exemplary nature of Christ's sacrifice (85-6) adequately describes Paul's thought in Romans.

${ }^{20} \mathrm{R}$. Corriveau, The Liturgy of Life, 177. 'It is this primordial union between Christ and the Christian, between Christian living and Christ's death and resurrection, which gives to the Christian and his life the essential quality of worship.' (185).

21J.D.G. Dunn, Word Biblical Commentary Volume 38B: Romans 9-16 (Waco, Word 1988) 709. Arguing this way, Dunn makes a closer link with the preceding context than others such as V.P. Furnish, Theology and Ethics in Paul (Nashville, Abingdon 1968) 101-2. However, Furnish rightly goes on to show that there are other ways in which the appeal in Rom. 12:1-2 recapitulates and focuses earlier motifs in Romans. 
argument of Romans 9-11 about the mercy of God in relation to Israel and the Gentiles (using $\varepsilon \lambda_{\varepsilon} \circ \varsigma$ and $\dot{\varepsilon} \lambda \varepsilon \varepsilon \hat{\imath} v$, rather than oi $\kappa \tau \imath \rho \mu$ ó $\varsigma$, which is the word for 'mercy' in 12:1). Behind Romans 9-11 stand the first eight chapters, where 'the reality of the mercy of God is never far from Paul's thought'.22 It is as if all God's merciful deeds, expounded so far in the letter, make their own appeal in Paul's exhortation. The invitation to join in the praise of God (11:33-6) leads to the challenge for his readers to respond to the mercies of God with the offering of their 'bodies' as a living sacrifice. The 'therefore' in Romans 12:1 is to be given its full force.

God's mercies, supremely expressed in the saving work of Jesus Christ, the gift of his Spirit, his perseverance with faithless Israel, and his gracious offer of salvation to the Gentiles (Romans 1-11), call forth the response of grateful obedience, with all the implications outlined in Romans 12-16. Paul's ethic is theologically grounded and theologically motivated. Christian obedience is an expression of gratitude for the blessings received from believing the gospel. 'God has redeemed us, therefore let us serve him!'23

In addressing his readers as $\alpha \delta \varepsilon \lambda \phi o i$ (NRSV, 'brothers and sisters'), Paul makes it clear that his entreaty is for those who know themselves to be the recipients of God's mercies and who are now united in the community of Christ. This call to worship is thus similar to Old Testament passages like Exodus 19:4-6; 20:1-3; Deuteronomy 10:14-22, where the redemptive initiative of God establishes and dictates the sort of 'divine service' that was required of Israel. The novelty of Paul's approach is that acceptable worship in the messianic era is essentially the presentation of ourselves to God on the basis of the single, atoning sacrifice of the death of Jesus, in the power of the Holy Spirit.

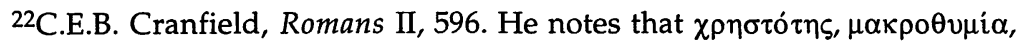
$\dot{\alpha} \gamma \dot{\alpha} \pi \eta$ and $\chi \alpha \dot{\rho} \rho \varsigma \varsigma$ predominate in Rom. 1-8, rather than the specific terms for mercy noted in Rom. 9-11. Such parallels suggest that 'the mercies of

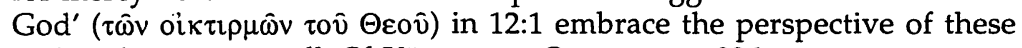
earlier chapters as well. Cf. Käsemann, Commentary, 326.

${ }^{23} \mathrm{O}$. O'Donovan, 'Evangelicalism and the Foundations of Ethics', in R. T. France and A. E. McGrath (eds.), Evangelical Anglicans. Their Role and Influence in the Church Today (London, SPCK 1993) 98. On the following pages he discusses the link between proclamation and prescription, the truths of the gospel and the action corresponding to them. 
We are sanctified or consecrated to God because Jesus Christ died and rose for us, and because the Spirit enables us to believe the gospel and yield ourselves to God (Rom. 15:16; $c f .1$ Cor. 1:2, 30; 2 Thes. 2:13; 1 Pet. 1:2). Consequently, the sacrifice we offer is already 'holy and pleasing to God' (Rom. 12:1). ${ }^{24} \mathrm{We}$ are holy, like the Israelites redeemed from Egypt, because God has graciously brought us to himself. However, that holiness needs to be expressed in our bodily life (Rom. 6:11-23; 1 Cor. 6:19-20; 2 Cor. 7:1), by living out the call to a holy life (1 Thes. $4: 1-12)$. Under the New Covenant 'we no longer have material offerings distinct from the giver but rather the personal offering of the body, of earthly life, inseparable from the existence of the one who offers. It is at this point that the holy merges with the ethical, with which it may so easily be equated'.25 The life that is truly acceptable to God is the life consecrated to him through self-abandonment to the saving work of Jesus Christ. It is the life that seeks to serve him in the context of everyday relationships and responsibilities, in the power of his Holy Spirit.

So the function of the worship terminology in Romans $12: 1$ is to proclaim the possibility of a new kind of service to God and to summon believers to respond to God's gracious initiative by the daily offering of themselves, in a whole-person commitment. The initial presentation of ourselves to God in Christ, made at conversion/baptism, needs to be renewed on a regular basis. ${ }^{26}$ This is the key to a life-transforming relationship with God, providing motivation and direction for the ethical teaching Paul is about to expound. Serving and pleasing God is really at the heart of Paul's teaching in the following chapters about responsibilities to those inside and outside the church (e.g., 13:1-7; 14:1-8, 17-18; 15:5-13).

${ }^{24}$ For the sacrifice or life acceptable to God, note other contexts where the

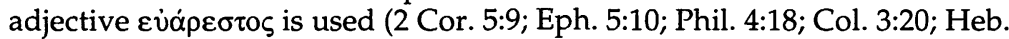
13:21). Similarly note the use of the adverb (Heb. 12:28) and the related verb (Heb. 11:5-6; 13:16).

${ }^{25} \mathrm{R}$. Corriveau, The Liturgy of Life, 171. Compare his comments on 2 Cor. $7: 1$.

${ }^{26}$ The aorist tense of $\pi \alpha \rho \alpha \sigma \tau \hat{\eta} \sigma \alpha \mathrm{\iota}$ considers this presentation of ourselves to God for his service holistically. The fact that Paul addresses those already committed to Christ in this letter suggests that the command is defining the response that is always to be regarded as the essence of Christian worship. 


\section{Intellect and ethics: 'the renewing of your mind'}

What is the relationship between the exhortation in Romans 12:2 and that of the preceding verse? Paul does not introduce a totally new topic, unconnected with the previous one. The renewal of the mind is bound up with the presentation of our bodies to God-there is no mind/body dualism here. Renewal of the mind begins as the gospel is understood and believed. This motivates and enables people to present themselves as a living sacrifice to God, for his service. However, if their sacrifice is to please God in the ongoing pressures and demands of everyday life, believers must continually be transformed by the renewal of their mind.

There is now a strong consensus of opinion that the two verbs $\sigma v \sigma \chi \eta \mu \alpha \tau i \zeta \varepsilon \sigma \theta \varepsilon$ ('be conformed') and $\mu \varepsilon \tau \alpha \mu \circ \rho \phi o v \sigma \theta \varepsilon$ ('be transformed') are more or less synonymous in Koine Greek. However, there is a difference of emphasis in the relevant clauses of Romans 12:2. The first warns against transformation

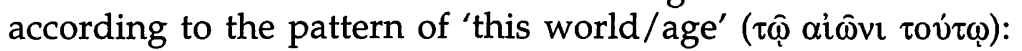
'Paul in effect recognizes the power of social groups, cultural norms, institutions, and traditions to mold the patterns of individual behavior'. ${ }^{27}$ The passive here points to the effect that such structures can have on us all. Paul does not call for escape from the world and its pressures but for a life in the world that is impelled and controlled by other factors. The passive of the second verb ( $\mu \varepsilon \tau \alpha \mu \rho \rho \phi 0 v \sigma \theta \varepsilon)$ suggests the transforming work of God, through his Spirit in the life of believers ( $c f$. Rom. 8:4; 8:13$14 ; 2$ Cor. 3:18). The Christian is to yield to the power of God and his norms, rather than to the influence of this age and its norms. The present imperative of both verbs points to the ongoing human responsibility involved in this process of change.

Käsemann rightly suggests an eschatological dimension to Paul's teaching with the use of $\alpha i \hat{\omega} v$ here: $\mu \varepsilon \tau \alpha \mu o \rho \phi o v \sigma \theta \theta_{l}$ is the transformation which, 'characterizes the change from the

27J.D.G. Dunn, Romans 9-16, 712. He endorses the distinction made by Harrisville: "'conform" refers to a posture or attitude that may be changed at will, whereas "form" at the heart of "transformed" refers to what grows out of necessity from an inward condition'. Note the full discussion of these two verbs by C.E.B. Cranfield, Romans II, 605-8. 
old to the new aeon'.28 As we allow ourselves to be moulded by the norms and patterns of the new age, we exhibit to the world the certainty and the character of the coming order that has already been manifested in Jesus. 'Christian existence, publicly offered to God corporeally as a sacrifice, is in all circumstances a pointer to the new world which has come in Christ, to the kingdom of Christ.'29

Transformation of the life that is offered to God (v. 1) takes place from within, by the renewal of the mind ( $\tau \hat{n}$

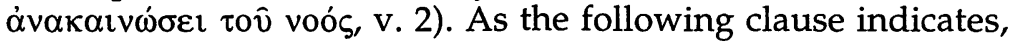
Paul is thinking about the mind as the faculty which enables us

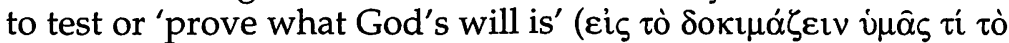
$\theta \dot{\varepsilon} \lambda \eta \mu \alpha$ tov̂ $\Theta \varepsilon \circ \hat{v}) .{ }^{30}$ Renewal of the mind makes it possible for us to go on discerning God's will and presenting ourselves for daily obedience in the face of countless pressures to do otherwise. This discovery of and dedication to God's will is made possible by the initial presentation of ourselves to God in Christ. 31

Paul's challenge in 12:2 implies that the human mind, apart from such renewal, is unable to guide and keep us in the life that is pleasing to God. That is certainly the conclusion of $1: 28$, which asserts that, since humanity 'did not think it

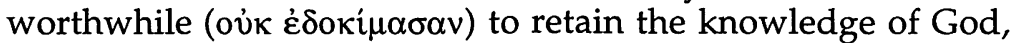

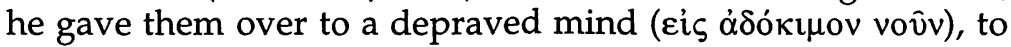

${ }^{28}$ Commentary, 329. Together with V.P. Furnish, Ethics, 105-6, he argues from Paul's use of several catchwords that this is a 'baptismal exhortation'. But this is a case of special pleading, reading back later Christian thinking and practice into NT times. Such terms as 'renewal' and 'transformation' are linked to the work of the Spirit in the NT but not necessarily to baptism.

${ }^{29}$ Commentary, 330. Cf. J.D.G. Dunn, Romans II, 713, on the Jewish apocalyptic background to Paul's use of the language of transformation. M. Thompson, Clothed with Christ, 84-5, discusses the eschatological dimension to Christian transformation in Paul's thought.

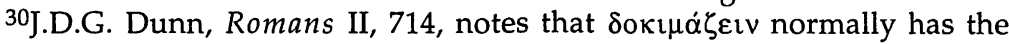
sense of 'test, examine, approve', but that here it overlaps with the use of Suakpiveıv (as used in 1 Cor. 14:29; Cf. 1 Cor. 2:13-15; 12:10; Did. 11:7) to mean 'the capacity of forming the correct Christian ethical judgement at each given moment'. Dunn takes this as a corporate, rather than a merely individualistic process, but does not argue his case with supporting evidence.

31For Paul's teaching about the discernment of God's will, cf. V.P. Furnish, Theology and Ethics, 188-91, 227-37. 
do what ought not to be done'.32 Despite their intellectual achievements, people live and act 'in the futility of their mind'

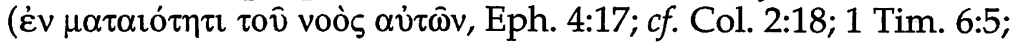
2 Tim. 3:8; Tit. 1:15), until they come to know Christ and are taught in accordance with the truth that is in Jesus. Then it is possible for them to be renewed in the attitude or 'spirit' of

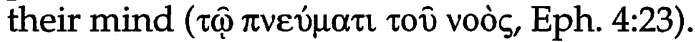

So the first two verses of Romans 12 are closely linked in Paul's thought and together proclaim a reversal of the downward spiral depicted in Romans 1:33

\section{wrath mercy}

refusing to glorify or thank God (thankful) sacrifice

dishonouring the body

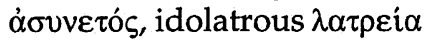
reprobate mind

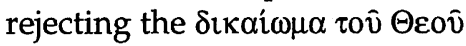
offering the body $\lambda$ oүıкทे $\lambda \alpha \tau \rho \varepsilon i \alpha$ renewed mind

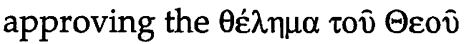

It is also possible that $12: 2$ is meant to form a deliberate contrast with 2:18, where the Jews claim to know God's will and

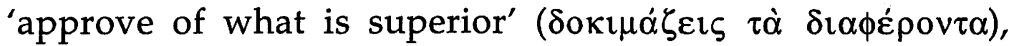
because they are instructed in the law of God. Paul's ethic is not law-determined but its objective is still 'the will of God'. Käsemann notes that when the will of God is described as 'that

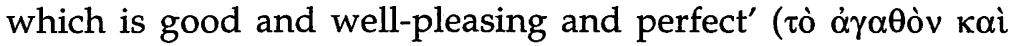

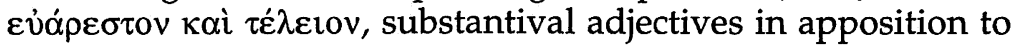

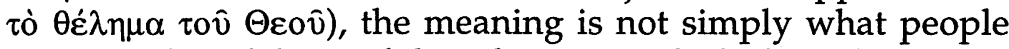
find good and beautiful and can justify before their own consciences. God's will may or may not coincide with human ideals. But God has given us minds so that we may 'perceive the demands of ethics and assess their obligatoriness'. Indeed,

in the light of the new aeon Christians can do a better job with reason than the world in general does. Paradoxically, they do this precisely at the point where, corresponding to God's will, they

${ }^{32}$ The play on words in Greek here suggests that, because people have rejected God as not worth reckoning with, he has delivered them into a condition 'in which their minds are fit only to be rejected as worthless, useless for their proper purpose, disreputable' (C.E.B. Cranfield, Romans I, 128).

${ }^{33}$ This chart is taken from M. Thompson, Clothed with Christ, 82. 
oppose the trend of this world and do what seems to be irrational, as God himself did in sending his Son to the cross. ${ }^{34}$

If we seek to discover more closely what the apostle meant by 'the will of God', it is clear that some measure of 'the good and well-pleasing' is given in the following chapters of Romans. Apostolic teaching will be a means of discerning the will of God in many life-situations. But 'the perfect' is a more comprehensive and absolute term, reminiscent of the demand of Jesus for whole-hearted and unconditional love for God and for neighbours (e. g., Mt. 5:43-8; 22:37-40). It is interesting to recall, then, that Paul begins his ethical teaching in Romans 12 with the foundational challenge to respond to God's claim for our bodies in worship. As the argument progresses, and certain moral and social implications of that commitment are outlined, Paul inserts a critical statement about neighbour-love being the fulfilment of the law (13:8-10). But the key to his argument is 'the willing and eager submission of the creature to live out of his dependence on God-to seek to know God's will as the first objective, and his enabling for the still harder task of doing it'. ${ }^{35}$

\section{Service in the body of Christ: the flow of the argument in Romans 12:3-21}

Käsemann rightly observes that Paul does not leave individual believers to their own opinions about the implications of their consecration to God.

The Spirit lays demands upon each individual completely and concretely in his particular relationships and makes him capable of a new manner of life. He does this at the same time in such a way that the individual shows himself thereby to be a member of the community. ${ }^{36}$

${ }^{34}$ Commentary, 331. Cf. J.D.G. Dunn, Romans II, 715-18, who argues that for Paul the law is still 'a moral yardstick and norm'. C.E.B. Cranfield, Romans II, 610-11, suggests that Paul's definition of the will of God in 12:2 may have been a reaction against perceived tendencies towards 'unethical mysticism' in the Roman church.

35J.D.G. Dunn, Romans II, 718.

${ }^{36}$ Commentary, 324, endorsing the argument of W. Schrage, Die konkreten Einzelgebote in der paulinischen Paränese (1961). C.H. Dodd's attempt to construct a schema of primitive Christian catechetics from Rom. 12-13 is criticised by Käsemann (Commentary, 326). 
Paul does not present a system of casuistry embracing all possible aspects of the life of the community and its members. His exhortation proceeds by way of example, addressing the community and relating the individual to that community.

A theme is advanced in v. 3 'which can be derived only indirectly from vv. 1-2 and which with a common Hellenistic play on words. . places the section which follows under the keyword $\sigma \omega \phi \rho o v \varepsilon i v^{\prime} .{ }^{37}$ What is at issue is the soberness which keeps the right 'measure of faith' ( $\mu \varepsilon \dot{\tau} \tau o v \pi i \sigma \tau \varepsilon \omega \varsigma)$. The apostle warns against arrogance in self-evaluation, particularly with respect to gifts for ministry. But only in a very limited sense can Paul's exhortation in verses 3-8 be described as 'ethics'. Käsemann thinks it would be more appropriate to speak of 'a doctrine of charisma' and heads this section 'Advice for Charismatics Who Stand Out!' Paul's 'anti-enthusiastic thrust' manifests itself in placing ecstatic ministries in parallel with administrative ministries (vv. 6-8). The validity of gifts is guaranteed only by their use in the service of the community. 'Not their presence but only their proper use is the criterion of their Christian nature.' 38

Käsemann denies that the rest of the chapter can be put under the heading of love. Rather, 'every activity of the Christian community is to be characterized as charismatic, because in this total activity the "spiritual worship" becomes real in the world'. 39 No system of Christian 'ethics' is being propounded here;

but for the first time in the history of the Church the total activity of the community and its members is being looked at from a unified perspective. It is theologically defined as the response of faith in the

${ }^{37}$ Commentary, 332. Cf. New Testament Questions, 192-3. Käsemann believes that Paul 'falls back surprisingly on Greek ethics' here, with the use of this verb. Aristotle, Nic. Eth. 1117b.13, identifies $\sigma \omega \phi \rho о \sigma v i v \eta$ as one of the four cardinal virtues. For Paul, this borrowing was 'mediated by popular philosophy through the Diaspora synagogue'.

${ }^{38}$ Commentary, 333. The connection with v. 2 is that the call for renewed and critical reason will have to 'stand the test in relation to the gifts of the Spirit' (334).

${ }^{39}$ New Testament Questions, 195. He who walks 'in Christ' or 'in the Spirit' lives by the power of grace and his activity is a manifestation of it. 'Even his "ethical" existence is understood eschatologically in Paul and the concept of charisma is intended to demonstrate this as clearly as possible.' 
everyday life of the world to the call of grace by which that world is being grasped and held. 40

Käsemann wants to emphasise that every Christian is a 'charismatic', that the gifts received by each must be verified in daily life, and that there is no distinction to be made between 'office' and 'community' or between 'private' and 'public' virtues in Paul's thinking.

There are profound insights here, but in the end I think that Käsemann has overstated his case. It is special pleading to say that love is simply one mode of behaviour among others in this chapter. Käsemann himself suggests that love is the 'supreme goal' of ministries in the body of Christ.41 The term itself is not used in verses 3-8 but the notion is implicit in all that Paul says in this paragraph. The importance of love is made explicit in verses 9-10 with the use of several significant

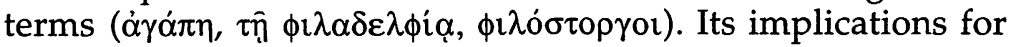
believers are then detailed in terms of their relationships with one another (vv. 9-16) and their relationships with opponents (vv. 17-21). The theme of love is highlighted again in 13:6-10, in a pivotal passage justifying the call to 'let no debt remain outstanding'. When Paul gets back to the problems affecting relationships amongst believers in Rome (14:1-15:13), it is clear that his teaching on love has been a particularly important preparation and foundation for that critical argument.

So the flow of the argument in Romans 12 is this. Paul first summons believers to respond to God's mercies with 'understanding worship', presenting themselves to God in a whole-person commitment (v. 1). But their 'living sacrifice' can only remain 'holy and pleasing to God' if they continue to be transformed by the renewal of their mind and do not submit to the standards and values of this age (v. 2). An inflated sense of self-importance is 'the first area of their thinking which needs transformation' (v. 3). 42 Believers need to view themselves as members of the body of Christ, each with gifts and responsibilities to be exercised for the benefit of others (vv. 4-8). With these exhortations, Paul is effectively teaching about the primacy of love. Those who measure themselves by the standard which God has given them 'in their faith' will not fail

40Ibid., 195. Cf. Commentary, 343-5.

${ }^{41}$ Commentary, 333.

${ }^{42} \mathrm{M}$. Thompson, Clothed with Christ, 87, following C.K. Barrett. 
to discern the one body and the implications of being 'members of one another' ( $\left.\dot{\alpha} \lambda \lambda \dot{\eta} \lambda \omega \nu \mu \dot{\varepsilon}^{\prime} \lambda \eta, v .5\right) .{ }^{43}$ Acceptance of the gospel is bound to have a corporate expression. Paul then highlights love as the attitude which must find expression amongst Christians, in their relationships generally (vv. 9-21). Such love is the essential sign of the renewing of the mind and of the transforming presence of the Spirit of God. As believers have their minds renewed and learn to love one another within the Christian fellowship, they are equipped by God to serve him and please him in every sphere of life.

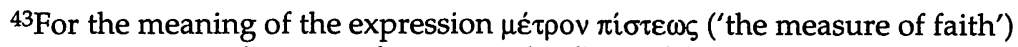
in Rom. 12:3 and its significance in the flow of the argument, $c f$. C.E.B. Cranfield, Romans II, 613-7. Contrast J.D.G. Dunn, Romans II, 721-2. 